\title{
Interleukin 10 acts on regulatory $T$ cells to maintain expression of the transcription factor Foxp3 and suppressive function in mice with colitis
}

\author{
Masako Murai ${ }^{1}$, Olga Turovskaya ${ }^{1}$, Gisen Kim ${ }^{1}$, Rajat Madan ${ }^{2}$, Christopher L Karp ${ }^{2}$, Hilde \\ Cheroutre $^{1}$, and Mitchell Kronenberg ${ }^{1}$ \\ ${ }^{1}$ Division of Developmental Immunology, La Jolla Institute for Allergy and Immunology, La Jolla, \\ California, USA. \\ 2Division of Molecular Immunology, Cincinnati Children's Hospital Medical Center and University \\ of Cincinnati College of Medicine, Cincinnati, Ohio, USA.
}

\begin{abstract}
Regulatory $\mathrm{T}$ cells $\left(\mathrm{T}_{\text {reg }}\right.$ cells) that express the transcription factor Foxp3 suppress the activity of other cells. Here we show that interleukin 10 (IL-10) produced by $\mathrm{CD}_{11} \mathrm{~b}^{+}$myeloid cells in recombination-activating gene 1-deficient $\left(\mathrm{Ragl}^{-1-}\right)$ recipient mice was needed to prevent the colitis induced by transferred CD4 ${ }^{+} \mathrm{CD} 45 \mathrm{RB}^{\text {hi }} \mathrm{T}$ cells. In $I l 10^{-/-} \mathrm{Rag}^{-1-}$ mice, $\mathrm{T}_{\text {reg }}$ cells failed to maintain Foxp3 expression and regulatory activity. The loss of Foxp3 expression occurred only in recipients with colitis, which indicates that the requirement for IL-10 is manifested in the presence of inflammation. IL-10 receptor-deficient $\left(I l 10 \mathrm{rb}^{-1-}\right) \mathrm{T}_{\text {reg }}$ cells also failed to maintain Foxp3 expression, which suggested that host IL-10 acted directly on the $\mathrm{T}_{\text {reg }}$ cells. Our data indicate that IL-10 released from myeloid cells acts in a paracrine manner on $\mathrm{T}_{\text {reg }}$ cells to maintain Foxp3 expression.
\end{abstract}

$\mathrm{CD}^{+}$regulatory $\mathrm{T}$ cells $\left(\mathrm{T}_{\text {reg }}\right.$ cells) express the transcription factor Foxp3 (A002750), which is required for their suppressive function. A T cell-transfer model of colitis has been widely used to study the function of $\mathrm{T}_{\text {reg }}$ cells in vivo. When $\mathrm{CD} 4{ }^{+} \mathrm{CD} 45 \mathrm{RB}{ }^{\text {hi }} \mathrm{T}$ cells are transferred into immunodeficient mice, some of the transferred $\mathrm{T}$ cells secrete proinflammatory cytokines and induce an inflammatory bowel disease-like syndrome ${ }^{1,2}$. Cotransfer of sufficient numbers of $\mathrm{T}_{\text {reg }}$ cells can prevent or even cure this disease ${ }^{3,4}$. The transferred $\mathrm{T}_{\text {reg }}$ cell populations expand considerably in vivo, and most maintain Foxp3 expression $^{5,6}$.

Mice deficient in interleukin 10 (IL-10 (A001243); $I l 10^{-/-}$mice) or the IL-10 receptor $\beta$ chain (IL-10R $\beta$ (A001245); IllOrb ${ }^{-1-}$ mice) develop spontaneous inflammation of the large intestine, a process dominated by a $\mathrm{T}$ helper type 1 immune response $7^{, 8}$. Many cell types

(C) 2009 Nature America, Inc. All rights reserved.

Correspondence should be addressed to M.K. (mitch@liai.org).

Reprints and permissions information is available online at http://npg.nature.com/reprintsandpermissions/.

Accession codes. UCSD-Nature Signaling Gateway (http://www.signaling-gateway.org): A002750, A001243 and A001245.

Note: Supplementary information is available on the Nature Immunology website.

AUTHOR CONTRIBUTIONS

M.M. and M.K. designed experiments; M.M. did experiments; O.T. did histology and helped with cell preparation; R.M. and C.L.K. generated and provided IL-10 reporter mice; G.K. and H.C. helped with critical advice and discussions throughout; and M.M. and M.K. wrote the manuscript. 
can produce IL-10, however, and therefore the IL-10 source(s) needed to prevent inflammation must be identified. Much emphasis has been placed on the role of IL-10 released by $\mathrm{CD}^{+}{ }^{+} \mathrm{T}$ cells, and in fact mice with conditional deletion of IL-10 in the CD4 ${ }^{+}$ subset develop spontaneous inflammation of the intestine ${ }^{9}$. Mice with deletion of IL-10 solely in Foxp $3^{+}$cells also develop inflammation in the intestine and elsewhere, although the pathogenesis is less intense than that in mice completely lacking IL-10 (ref. 10). Transgenic mice that overexpress IL-10 in intestinal epithelial cells are protected from colitis 11, which suggests that IL-10 from nonlymphoid sources can be beneficial, although altered expression in the transgenic mice may not be physiologically relevant.

To further elucidate the cellular and molecular basis of the function of IL-10 in regulating colitis, we used the T cell-transfer model described above. We found that IL-10 from nonlymphoid cells, particularly $\mathrm{CD} 11 \mathrm{~b}^{+} \mathrm{CD} 11 \mathrm{c}^{+}$cells, had an unexpectedly important influence on the development of colitis. Furthermore, we provide evidence that this IL-10 acted in part on $\mathrm{T}_{\text {reg }}$ cells to maintain their expression of Foxp3, which was otherwise lost in inflammatory conditions after transfer.

\section{RESULTS}

\section{Colitis prevention by $1110^{-/-} \mathrm{T}_{\text {reg }}$ cells}

Several studies have suggested that IL-10 production by $\mathrm{T}_{\text {reg }}$ cells is required for the prevention of colitis ${ }^{10,12,13}$. However, some studies suggest that $\mathrm{T}_{\text {reg }}$ cell-derived IL-10 is less important than other studies do ${ }^{14,15}$. To assess the suppressive function of $I l 10^{-1-} \mathrm{CD} 4^{+} \mathrm{CD} 25^{+} \mathrm{T}_{\text {reg }}$ cells, we did both in vitro and in vivo experiments. $I l 10^{-1-}$ $\mathrm{CD} 4^{+} \mathrm{CD} 25^{+} \mathrm{T}_{\text {reg }}$ cells were as capable as wild-type cells of inhibiting the proliferation of $\mathrm{CD}^{+} \mathrm{CD} 45 \mathrm{RB}^{\text {hi }} \mathrm{T}$ cells in vitro (data not shown). For in vivo analysis, we transferred sorted $\mathrm{CD} 4{ }^{+} \mathrm{CD} 45 \mathrm{RB}^{\text {hi }} \mathrm{T}$ cells together with sorted $\mathrm{CD} 4{ }^{+} \mathrm{CD} 45 \mathrm{RB}^{\mathrm{lo}} \mathrm{CD} 25^{+} \mathrm{T}_{\text {reg }}$ cells from wildtype or $1110^{-1-}$ mice into recombination-activation gene $1-$ deficient $\left(\right.$ Rag $\left.^{-1-}\right)$ mice. As a positive control for colitis induction, we injected $C D 4^{+} \mathrm{CD} 45 \mathrm{RB}^{\text {hi }} \mathrm{T}$ cells without $\mathrm{T}_{\text {reg }}$ cells. Host mice given either wild-type or $I l 10^{-1-} \mathrm{T}_{\text {reg }}$ cells remained healthy without losing body weight (Fig. 1a) and survived for more than 4 months after transfer (data not shown). The average histology scores of recipients of wild-type or $1110^{-1-} \mathrm{T}_{\text {reg }}$ cells were similar and were indicative of a low degree of inflammation compared with that of mice that did not receive $T_{\text {reg }}$ cells (Fig. 1b). These findings show that $I L-10$ derived from $T_{\text {reg }}$ cells was dispensable for the prevention of colitis in our mice.

\section{Host IL-10 is required for colitis suppression}

The negative results of the analysis of $\mathrm{T}_{\text {reg }}$ cell-derived IL-10 raised the issue of the possible involvement of host-derived IL-10 in the inhibition of colonic inflammation. To address this possibility, we used $I l 10^{-/-} \mathrm{Ragl}^{-/-}$mice as recipients in transfer experiments. These mice did not spontaneously develop colitis (data not shown); however, both $\operatorname{Ragl}^{-/-}$ and $1 l 10^{-1-} \mathrm{Rag}^{-/-}$recipients of $\mathrm{CD}^{+}{ }^{+} \mathrm{CD} 45 \mathrm{RB}^{\text {hi }} \mathrm{T}$ cells had lost approximately $20 \%$ of their initial weight at 8 weeks after donor cell injection (Supplementary Fig. 1a). The severity of colitis in $\mathrm{Ragl}^{-/-}$mice was similar to that in the $1110^{-/-} \mathrm{Ragl}^{-/-}$hosts (Supplementary Fig. 1b), which suggested that host-derived IL-10 did not have a major effect on the colitis pathogenesis induced by the transferred T cell population.

Next we determined if host-derived IL-10 was essential for $\mathrm{T}_{\text {reg }}$ cell-mediated prevention of colitis. To more precisely define the transferred $\mathrm{T}_{\text {reg }}$ cell population, we used reporter mice with sequence encoding green fluorescent protein (GFP) inserted inframe into the Foxp3 gene $\left(F_{\text {oxp }} 3^{\mathrm{gfp}}\right)^{16}$. We selected the $\mathrm{T}_{\text {reg }}$ cell population from these mice on the basis of green fluorescence, as well as expression of CD25, CD4 and small amounts of CD45RB. 
The selected cells were up to $99 \%$ Foxp $3^{+}$(Supplementary Fig. 2). We transferred CD45.1 ${ }^{+}$ $\mathrm{CD}^{+} \mathrm{CD} 45 \mathrm{RB}^{\text {hi }} \mathrm{T}$ cells together with CD45.2 $2^{+}$Foxp $3^{\mathrm{gfp}} \mathrm{T}_{\text {reg }}$ cells into either Rag $1^{-1-}$ or $I l 10^{-/-} \mathrm{Ragl}^{-1-}$ hosts so that the two donor T cell populations could be distinguished on the basis of their CD45 alleles. As expected, Rag $1^{-1-}$ hosts that received $\mathrm{CD} 4{ }^{+} \mathrm{CD} 45 \mathrm{RB}{ }^{\text {hi }} \mathrm{T}$ lymphocytes and $\mathrm{T}_{\text {reg }}$ cells did not lose weight (Fig. 2a). Unexpectedly, at 5 weeks after transfer, $I l 10^{-I-} \mathrm{RagI}^{-1-}$ hosts injected with $\mathrm{CD} 4^{+} \mathrm{CD} 45 \mathrm{RB}^{\text {hi }} \mathrm{T}$ lymphocytes and $\mathrm{T}_{\text {reg }}$ cells showed a weight loss of nearly $20 \%$ (Fig. 2a), similar to that induced by transfer of $\mathrm{CD} 4{ }^{+} \mathrm{CD} 45 \mathrm{RB}^{\text {hi }} \mathrm{T}$ cells alone. Furthermore, $I l 10^{-/-} \mathrm{Ragl}^{-1-}$ recipients developed colonic inflammation characterized by the infiltration of mononuclear cells, loss of goblet cells and epithelial cell hyperplasia in both the distal colon (data not shown) and proximal colon (Fig. $2 \mathrm{~b}, \mathrm{c})$. We obtained similar results with $\mathrm{T}_{\text {reg }}$ cells isolated from wild-type mice and sorted on the basis of CD25, CD4 and CD45RB ${ }^{\text {lo }}$ expression alone (data not shown), which indicated that the results presented above were not related to the insertion of the gene encoding GFP into the Foxp 3 locus. These findings suggest that host-derived IL-10 is required for $\mathrm{T}_{\text {reg }}$ cell-mediated prevention of colitis.

\section{Lower Foxp3 expression in $/ 11^{-/-}$Rag $1^{-/-}$recipients}

To determine if the $T_{\text {reg }}$ cells underwent population expansion and homed to different tissues in the absence of host IL-10, we collected lymphocytes from the lamina propria of the large intestine (LPL), spleen, peripheral lymph nodes (PLNs; inguinal and axillary) and mesenteric lymph nodes (MLNs); we separately analyzed by flow cytometry the CD45.1 $1^{+}$ progeny of $\mathrm{CD} 4^{+} \mathrm{CD} 45 \mathrm{RB}^{\text {hi }} \mathrm{T}$ cells and the $\mathrm{CD} 45.2^{+}$progeny of $\mathrm{T}_{\text {reg }}$ cells sorted from Foxp $3^{\mathrm{gfp}}$ mice. By 6 weeks after donor cell injection, the CD $45.1^{+}$cell/CD $45.2^{+}$cell ratios in $\mathrm{Ragl}^{-/-}$and $I l 1 \mathrm{O}^{-1-} \mathrm{Ragl}^{-/-}$hosts were maintained at approximately the starting ratio of 4:1 in each of the organs analyzed (Fig. 3a). This suggested that the population expansion of Foxp $3^{\text {gfp }} \mathrm{T}_{\text {reg }}$ cells in vivo was similar to that of the $\mathrm{CD}^{+} \mathrm{CD}^{2} 5 \mathrm{RB}^{\text {hi }} \mathrm{T}$ cells in $R a g 1^{-l-}$ and Ill1 ${ }^{-1-}$ Rag $1^{-/-}$hosts.

Unexpectedly, however, $\mathrm{T}_{\text {reg }}$ cells in $I l 10^{-/-} \mathrm{Ragl}^{-/-}$hosts showed profound downregulation of the expression of Foxp3 protein (Fig. 3b,c) and Foxp3 mRNA (data not shown). In contrast, $\mathrm{T}_{\text {reg }}$ cells transferred into $\mathrm{Ragl}^{-/-}$hosts maintained Foxp3 expression, although the percentage of Foxp3-expressing progeny of sorted $\mathrm{T}_{\text {reg }}$ cells in the lamina propria was less than that in the lymphoid organs (Fig. $3 \mathrm{~b}, \mathrm{c}$ ). The $\mathrm{T}_{\text {reg }}$ cells obtained from $1 l 1 \mathrm{O}^{-/-} \mathrm{RagI}^{-{ }^{--}}$and $\mathrm{Ragl}^{-/-}$hosts expressed similar amounts of the immunomodulatory receptor GITR and cytokine receptor CD25 (data not shown). We detected some loss of Foxp3 expression, especially in LPL, as early as $2-3$ weeks after transfer (Supplementary Fig. 3), the earliest times at which transferred $\mathrm{T}_{\text {reg }}$ cells were readily detectable.

To determine if $\mathrm{T}_{\text {reg }}$ cells from $I l 10^{-/-} \mathrm{Rag}^{-/-}$hosts had altered function, we assessed cytokine production. At 6 weeks after donor cell injection, $\mathrm{CD} 4{ }^{+} \mathrm{CD} 45 \mathrm{RB}^{\mathrm{hi}}\left(\mathrm{CD} 45.1^{+}\right) \mathrm{T}$ cells obtained from $I l 10^{-/-}$Rag $1^{-/-}$hosts produced interferon- $\gamma$ (IFN- $\gamma$ ) when stimulated in vitro with phorbol 12-myristate 13-acetate (PMA) and ionomycin (Fig. 4a). In addition, some of these cells produced IL-17 (Supplementary Fig. 4) and tumor necrosis factor (data not shown). In contrast, $\mathrm{CD} 4{ }^{+} \mathrm{CD} 45 \mathrm{RB}^{\text {hi }} \mathrm{T}$ cells obtained from $\mathrm{Rag}^{-1-}$ hosts did not produce IFN- $\gamma$ or other proinflammatory cytokines after restimulation (Fig. 4a), which probably reflected the suppressive activity of the cotransferred $\mathrm{T}_{\text {reg }}$ cells.

Notably, CD45.2 $2^{+}$progeny of $\mathrm{T}_{\text {reg }}$ cells obtained from all organs of $I l 10^{-/-} \mathrm{Ragl}^{-/-}$hosts also produced IFN- $\gamma$ after restimulation, although this was less evident in the spleen than in the mucosal immune system (Fig. 4b). These cells, however, did not produce IL-17 (Supplementary Fig. 4) or tumor necrosis factor (data not shown), which distinguishes their cytokine profile from that of the $\mathrm{CD} 45.1^{+} \mathrm{CD} 4{ }^{+} \mathrm{CD} 45 \mathrm{RB}^{\text {hi }} \mathrm{T}$ cells obtained from the same recipients. In agreement with their ability to produce IFN- $\gamma$, the CD45.2 $2^{+}$progeny of $\mathrm{T}_{\text {reg }}$ 
cells transferred into $1 / 10^{-/-} \mathrm{Ragl}^{-/-}$recipients also expressed the transcription factor T-box 21 (also called T-bet), as detected by flow cytometry and RT-PCR (data not shown). Consistent with their maintenance of Foxp3 expression, the progeny of sorted $\mathrm{T}_{\text {reg }}$ cells obtained from $\mathrm{Ragl}^{-/-}$hosts did not produce IFN- $\gamma$ (Fig. 4b), IL-17 or tumor necrosis factor and they did not express T-bet (data not shown).

The distinct cytokine profile of the cells that previously expressed Foxp3, compared with that of their $\mathrm{CD} 4^{+} \mathrm{CD} 45 \mathrm{RB}^{\mathrm{hi}}$ counterparts, suggested that these cells were not derived from the progeny of a small number of contaminating $\mathrm{CD} 4{ }^{+} \mathrm{CD} 45 \mathrm{RB} \mathrm{Bi}^{\text {hi }}$ To determine if contaminating $\mathrm{CD}^{+} \mathrm{T}$ lymphocytes with an activated memory phenotype could have outgrown the transferred $\mathrm{T}_{\text {reg }}$ cells in IL-10-deficient conditions, we transferred CD90.1 ${ }^{+}$ $\mathrm{CD} 4^{+} \mathrm{CD} 45 \mathrm{RB}^{\text {hi }}$ cells together with CD $45.2^{+} \mathrm{T}_{\text {reg }}$ cells and CD45.1 $1^{+}$ CD $44{ }^{\text {hi }}{ }^{\mathrm{CD}} 62 \mathrm{~L}^{-}{ }^{-}$oxp $3{ }^{-}$cells with an activated memory phenotype into $I l 10^{-1-} \mathrm{Ragl}^{-1-}$ hosts. The number of memory cells transferred was $3 \%$ the number of $\mathrm{T}_{\text {reg }}$ cells, a degree of impurity greater than that in the transferred $\mathrm{T}_{\text {reg }}$ cell populations that were enriched by flow cytometry. These memory cells did not outgrow the transferred $\mathrm{T}_{\text {reg }}$ cells in MLNs, perhaps outgrew them only slightly in spleen and were under-represented in lamina propria when analyzed 2 weeks after transfer (Supplementary Fig. 5). At this time, however, up to 50\% of the original transferred $\mathrm{T}_{\text {reg }}$ cell population had lost Foxp3 expression.

To further define the function of the transferred $\mathrm{T}_{\text {reg }}$ cells, we assessed their suppressive activity in vitro. We sorted $\mathrm{T}_{\text {reg }}$ cells on the basis of CD45.2 expression from the MLNs of recipients at 6 weeks after donor cell injection. We cultured $\mathrm{T}_{\text {reg }}$ cells obtained from $\mathrm{Ragl}^{-1-}$ or $I l 1 \mathrm{O}^{-/-} \mathrm{Ragl}^{-1-}$ recipients with carboxyfluorescein succinimidyl ester (CFSE)labeled splenic $\mathrm{CD} 45.1^{+} \mathrm{CD} 4^{+} \mathrm{CD} 25^{-} \mathrm{T}$ cells obtained from wild-type mice. Whereas $\mathrm{T}_{\text {reg }}$ cells recovered from $\mathrm{Ragl}^{-/-}$hosts suppressed the proliferation of the CFSE-labeled naive $\mathrm{CD}^{+} \mathrm{T}$ cells, $\mathrm{T}_{\text {reg }}$ cells isolated from $I l 1 \mathrm{O}^{-l-} \mathrm{Ragl}^{-l-}$ recipients failed to suppress the proliferation of naive T cells (Fig. 4c). Collectively these findings show that IL-10 produced by cells in $\mathrm{Ragl}^{-/-}$mice is required for the maintenance of Foxp3 expression and the suppressive activity of transferred $\mathrm{T}_{\text {reg }}$ cells.

\section{II10rb-/- $\mathrm{T}_{\text {reg }}$ cells do not prevent colitis}

IL-10 produced by cells in the $R a g 1^{-1-}$ hosts may act directly on the transferred $\mathrm{T}_{\text {reg }}$ cells or may act on some other cell type, such as dendritic cells, which might be involved in stabilizing Foxp3 expression. To test for a direct effect of IL-10 on transferred $\mathrm{T}_{\text {reg }}$ cells, we compared the ability of $\mathrm{T}_{\text {reg }}$ cells from wild-type and $1110 \mathrm{rb}^{-/-}$mice to suppress colitis in Rag $1^{-/}$hosts, with Foxp $3^{\text {gfp }}$ mice crossed to $I l 10 \mathrm{rb}^{-/-}$mice as a source of 'marked' $\mathrm{T}_{\text {reg }}$ cells. The percentage of Foxp $3^{\text {gfp }} \mathrm{T}_{\text {reg }}$ cells in 6- to 7-week-old $1110 \mathrm{rb} \mathrm{r}^{-1-}$ mice, which were generally healthy, was similar to that in wild-type mice (Supplementary Fig. 6a). Furthermore, Foxp $3^{\text {gfp }} \mathrm{T}$ cells from $1 / 1 \mathrm{Orb}^{-/-}$mice were as capable as wild-type cells of inhibiting the proliferation of $\mathrm{CD}^{+}{ }^{+} \mathrm{CD} 45 \mathrm{RB}^{\text {hi }} \mathrm{T}$ cells in vitro (Supplementary Fig. 6b). However, Ragl $^{-l-}$ recipients of $\mathrm{CD} 4^{+} \mathrm{CD} 45 \mathrm{RB}^{\text {hi }} \mathrm{T}$ cells and $1110 \mathrm{rb}^{-/-} \mathrm{T}$ cells had only approximately $20 \%$ of their initial starting weight by 4 weeks after donor cell injection (Fig. 5a). Moreover, these mice had severe colonic inflammation in both the distal colon (data not shown) and proximal colon (Fig. 5b,c). Similar to the outcome produced by transfer of wildtype $\mathrm{T}_{\text {reg }}$ cells into $111 \mathrm{O}^{-/-} \mathrm{Ragl}^{-/-}$hosts, transferred $1110 \mathrm{rb}^{-/-} \mathrm{T}$ cells showed profound downregulation of Foxp3 expression (Fig. 5d,e). These findings suggest that IL-10 signaling is required, at least in part in a $\mathrm{T}_{\text {reg }}$ cell-intrinsic manner, for the maintenance of Foxp3 expression and suppressive function. 


\section{Loss of Foxp3 expression requires inflammation}

It may be problematic to compare Foxp3 expression in $\mathrm{T}_{\text {reg }}$ cells in $\mathrm{Ragl}^{-/-}$and $I l 10^{-1-} \mathrm{Ragl}^{-1-}$ recipients, because only the latter recipients developed intestinal inflammation. It is possible that without IL-10 signaling, transferred $\mathrm{T}_{\text {reg }}$ cells are only marginally less effective, but that inflammation may amplify the loss of Foxp3 expression and $\mathrm{T}_{\text {reg }}$ cell function. Therefore, we did cotransfer experiments in which we injected equal numbers of allelically distinguishable wild-type $\left(\mathrm{CD} 45.1^{+}\right)$and $1110 \mathrm{rb}^{-1-}\left(\mathrm{CD} 45.2^{+}\right) \mathrm{T}_{\text {reg }}$ cells together with $\mathrm{CD} 4^{+} \mathrm{CD} 45 \mathrm{RB}^{\mathrm{hi}}\left(\mathrm{CD} 90.1^{+}\right) \mathrm{T}$ cells into $\mathrm{Rag} 1^{-1-}$ hosts and monitored each subset over time (Supplementary Fig. 7a). At a ratio of 20:1 (CD4 ${ }^{+} \mathrm{CD} 45 \mathrm{RB}{ }^{\text {hi }} \mathrm{T}$ cells/ $\mathrm{T}_{\text {reg }}$ cells), as anticipated, all mice that received either type of $\mathrm{T}_{\text {reg }}$ cells or the mixture developed colitis (Supplementary Fig. 7b,c). At 6 weeks after transfer, wild-type and $1110 \mathrm{rb}^{-1-} \mathrm{T}_{\text {reg }}$ cells recovered from these mice were present at approximately the starting ratio of 1:1 (Fig. 6a). Notably, however, IllOrb ${ }^{-1-} \mathrm{T}_{\text {reg }}$ cells tended to lose Foxp3 expression more than the wild-type $\mathrm{T}_{\text {reg }}$ cells in the same hosts did (Fig. 6b,c). Also, there was a somewhat greater tendency for the wild-type $\mathrm{T}_{\text {reg }}$ cells to lose Foxp3 expression in these recipient mice than in recipient mice in which sufficient numbers of $T_{\text {reg }}$ cells were present to prevent inflammation (Figs. $3 \mathrm{~b}$ and $5 \mathrm{~d}$ ). These results show that inflammation itself was not the sole factor that caused the loss of Foxp3 expression, although it may have contributed to this. Furthermore, our results suggest that there is a cell-intrinsic effect of the interaction of IL-10 with its receptor in the maintenance of Foxp3 expression in inflammatory conditions.

We also investigated whether the lack of IL-10 signaling in $T_{\text {reg }}$ cells caused the loss of Foxp3 expression when inflammation was not present. We transferred wild-type $\mathrm{T}_{\text {reg }}$ cells and $I l 10 \mathrm{rb}^{-l-} \mathrm{T}_{\text {reg }}$ cells (at a ratio of 1:1), along with $\mathrm{CD} 4^{+} \mathrm{CD} 45 \mathrm{RB}^{\text {hi }} \mathrm{T}$ cells, similar to the experiments described above but at a final ratio of 2:1 for $\mathrm{CD}^{+}{ }^{+} \mathrm{CD} 45 \mathrm{RB} \mathrm{B}^{\text {hi }} \mathrm{T}$ cells $/ \mathrm{T}_{\text {reg }}$ cells. In this case, the mice were completely protected from colitis (data not shown). In the absence of inflammation, the loss of Foxp3 expression by the transferred $1110 \mathrm{rb}^{-1-} \mathrm{T}_{\text {reg }}$ cells was blunted, and the maintenance of Foxp3 expression by cells in this population was similar to that of wild-type $\mathrm{T}_{\text {reg }}$ cells (Fig. 6d). In addition, when we transferred $\mathrm{T}_{\text {reg }}$ cells in the absence of $\mathrm{CD}^{+} \mathrm{CD} 45 \mathrm{RB}^{\text {hi }} \mathrm{T}$ cells, IllOrb ${ }^{-l-} \mathrm{T}_{\text {reg }}$ cells tended to not lose Foxp3 expression any more than wild-type $\mathrm{T}_{\text {reg }}$ cells did (data not shown). Collectively these data suggest that the loss of Foxp3 expression could be attributed to both the absence of IL-10 signaling in the $\mathrm{T}_{\text {reg }}$ cells and the presence of inflammatory signals and colitis in the hosts but that neither factor alone caused substantial loss of Foxp3. Therefore, unlike transforming growth factor- $\beta$, which is important for the homeostasis of natural $\mathrm{T}_{\text {reg }}$ cells ${ }^{17-22}$, IL-10 is important for maintaining Foxp3 expression once the $T_{\text {reg }}$ cells are differentiated and exposed to inflammation.

\section{Myeloid cells in the mucosa produce IL-10}

We next evaluated which cell types produced IL-10 in the ag $^{-/-}$recipients. We used IL-10 reporter mice in which an internal ribosome entry site upstream and the gene encoding GFP were inserted in $I l 10$ (Illogfp; 'Vert-X' mice). There was good concordance between GFP fluorescence and IL-10 production when we activated T lymphocytes from these mice in vivo (Supplementary Fig. 8). We used cells from these mice as a source of $\mathrm{CD}^{+}{ }^{+} \mathrm{CD} 45 \mathrm{RB}^{\text {hi }} \mathrm{T}$ lymphocytes and $\mathrm{T}_{\text {reg }}$ cells and also crossed these mice with Rag $1^{-/-}$ mice to track IL-10-producing nonlymphoid cells in the recipient mice.

As expected, before transfer, some $\mathrm{CD} 4{ }^{+} \mathrm{CD} 45 \mathrm{RB}^{\text {lo }} \mathrm{CD} 25^{+} \mathrm{T}_{\text {reg }}$ cells from the spleen were $\mathrm{GFP}^{+}$(an average of $4.0 \% \pm 1.2 \%$; Fig. 7a), as were some $\mathrm{T}_{\text {reg }}$ cells in MLNs (data not shown). In the $\mathrm{CD} 4^{+} \mathrm{CD} 45 \mathrm{RB}^{\text {hi }} \mathrm{T}$ cell population, in contrast, fewer cells expressed GFP (Fig. 7a). When we isolated lymphocytes from wild-type mice, stimulated them with PMA 
and ionomycin and analyzed IL-10 protein by intracellular cytokine staining, we found that IL- $10^{+}$cells were confined to the $\mathrm{T}_{\text {reg }}$ cell population and constituted a minority of this group (data not shown).

Analysis of nonlymphoid cells in the $\mathrm{Rag}^{-1-}$ recipients indicated that before $\mathrm{T}$ cell transfer, $3.7 \% \pm 0.9 \%$ of $\mathrm{CD}^{4} 5^{+}$cells from LPL of $1110^{\mathrm{gfp}} \mathrm{Rag}^{-/-}$mice expressed GFP (Fig. 7a); we detected a lower percentage of $\mathrm{GFP}^{+} \mathrm{CD}_{4} 5^{+}$cells in the MLNs and spleen, and $\mathrm{GFP}^{+}$cells were essentially undetectable in the CD45 $5^{-}$population in LPL and MLNs (Fig. 7a). We also analyzed GFP expression in $I l 10^{\mathrm{gfp}} \mathrm{Rag} \mathrm{I}^{-{ }^{--}}$recipients 1 week after cotransfer of CD45.1 ${ }^{+}$ $\mathrm{CD}^{+} \mathrm{CD} 45 \mathrm{RB}^{\text {hi }} \mathrm{T}$ cells and CD45.2 $2^{+}$Illogfp $\mathrm{T}_{\text {reg }}$ cells. We noted a much higher percentage of nonlymphoid cells in MLNs that were $\mathrm{GFP}^{+}$(an average of $7.8 \% \pm 1.8 \%$ of the CD45 cells; Fig. 7b). Most of these $\mathrm{GFP}^{+}$cells $(82.1 \% \pm 5.2 \%)$ were $\mathrm{CD}^{11 b^{+}, 62.1 \% \pm 9.6 \%}$ expressed both CD11b and CD11c, and most expressed the macrophage marker F4/80 (Supplementary Fig. 9). In contrast to cells in the MLNs, in the LPL, the percentage of $\mathrm{GFP}^{+} \mathrm{CD} 45^{+}$nonlymphoid cells was slightly lower by 1 week after transfer (an average of $2.7 \% \pm 0.8 \%$; Fig. $7 \mathrm{a}, \mathrm{b}$ ). The source of the greater number of $\mathrm{GFP}^{+} \mathrm{CD} 11 \mathrm{~b}^{+}$cells in MLN after transfer could have been due in part to migration from the LPL, although we cannot exclude the possibility of cell division or recruitment from other sources. At 1 week after transfer, in the LPL there were very few $\mathrm{GFP}^{+}$cells in the $\mathrm{CD} 45^{-}$population, and there was no higher GFP expression by gated CD $45.2^{+} I l 10^{\text {gfp }} \mathrm{T}_{\text {reg }}$ cells (an average of 3.0\% $\pm 0.6 \%$ ) than by the donor population of splenic $\mathrm{T}_{\text {reg }}$ cells (Fig. 7a,b).

To further define the kinetics of IL-10 production, we analyzed $I l 10$ mRNA by real-time PCR. Before donor cell injection, $\mathrm{T}_{\text {reg }}$ cells contained 40 times more $I l 10$ transcripts than did $\mathrm{CD}^{+} \mathrm{CD}^{2} 5 \mathrm{RB}^{\text {hi }} \mathrm{T}$ cells (Fig. 7c). These data are consistent with the greater percentage of $\mathrm{GFP}^{+}$cells in $\mathrm{T}_{\text {reg }}$ cells in the IL-10 reporter mice (Fig. 7a). Before donor cell injection, $\mathrm{CD} 11 \mathrm{c}^{+} \mathrm{CD} 11 \mathrm{~b}^{+}$cells of the LPL contained almost four times more $I l 10$ transcripts than did $\mathrm{T}_{\text {reg }}$ cells (Fig. 7c), whereas CD11 $\mathrm{c}^{+} \mathrm{CD} 11 \mathrm{~b}^{+}$cells of the MLNs had less $I l 10$ mRNA than did either $\mathrm{T}_{\text {reg }}$ cells or their counterparts in the LPL (Fig. 7c). At 1 week after injection of $\mathrm{CD} 45.1^{+} \mathrm{CD}^{+}{ }^{+} \mathrm{CD} 45 \mathrm{RB}^{\mathrm{hi}} \mathrm{T}$ cells and CD45.2 ${ }^{+}$Illo $0^{\mathrm{gfp}} \mathrm{T}_{\text {reg }}$ cells, however, there were substantial changes in the expression of $I l 10 \mathrm{mRNA}$ in the nonlymphoid cell populations in the intestine. $I l 10$ transcripts in the $\mathrm{CD} 11 \mathrm{c}^{+} \mathrm{CD} 11 \mathrm{~b}^{+} \mathrm{F} 4 / 80^{+}$cells from MLNs were 6.6-fold more abundant, whereas 1110 mRNA in the same population from the LPL was slightly less abundant (Fig. 7c). These alterations in mRNA are in agreement with the changes in $\mathrm{GFP}^{+}$ cells in the IL-10 reporter mice (Fig. 7b). The greater abundance of $I l 10$ mRNA in $\mathrm{CD} 11 \mathrm{c}^{+} \mathrm{CD} 11 \mathrm{~b}^{+} \mathrm{F} 4 / 80^{+}$cells in MLNs was transient, however, and peaked at 1 week after donor cell injection. Illo mRNA in $\mathrm{T}_{\text {reg }}$ cells increased much later, and the increase occurred selectively in the LPL (Fig. 7c). Those sorted CD11 $\mathrm{c}^{+}$cells that did not express macrophage markers (CD11b and F4/80) and were probably dendritic cells did not induce Illo mRNA at any time after T cell transfer (Fig. 7c).

To determine if IL-10 production by myeloid cells was important for the maintenance of Foxp3 expression by $\mathrm{T}_{\text {reg }}$ cells, we transferred $\mathrm{CD} 11 \mathrm{c}^{+} \mathrm{CD} 11 \mathrm{~b}^{+} \mathrm{F} 4 / 80^{+}$cells from the LPL of Rag $1^{-/-}$or $I l 10^{-/-} \mathrm{Ragl}^{-/-}$mice into $I l 1 \mathrm{O}^{-1-} \mathrm{Ragl}^{-{ }^{--}}$recipients. When the myeloid cells were derived from $\mathrm{Ragl}^{-/-}$donors, the loss of Foxp3 expression by $\mathrm{T}_{\text {reg }}$ cells was less than that produced by transfer of the same population from $I l 10^{-1-} \mathrm{Ragl}^{-/-}$donors (Fig. 8a). Furthermore, this effect was specific to the $\mathrm{CD} 11 \mathrm{~b}^{+}$cells, as transfer of the same number of $\mathrm{CD} 11 \mathrm{c}^{+} \mathrm{CD} 11 \mathrm{~b}^{-} \mathrm{F} 4 / 80^{-}$cells was not effective in stabilizing Foxp3 expression (Fig. 8b). We conclude that $\mathrm{CD}_{11 \mathrm{~b}^{+}}$myeloid cells, perhaps mostly macrophages, are key producers of IL-10 in the intestine at early times after $\mathrm{T}$ cell transfer and that this IL-10 is necessary for maintenance of Foxp3 expression in $\mathrm{T}_{\text {reg }}$ cells. 


\section{DISCUSSION}

The results from several studies have indicated that T cell-derived IL-10 is important for the prevention of colitis $9,10,12,23$. However, here we did not identify a major role for $\mathrm{T}_{\text {reg }}$ cellderived IL-10 in the transfer model of colitis. The reasons for our discordant findings could reflect aspects of the endogenous flora in different colonies and/or the intensity of the pathogenesis. Regardless of the source of the discrepancy, our results have demonstrated that in some circumstances, $\mathrm{T}_{\text {reg }}$ cells can prevent colitis by means other than IL-10 secretion. Most notably, we made the unexpected observation that IL-10 produced by cells other than $\mathrm{T}$ lymphocytes was required for $\mathrm{T}_{\text {reg }}$ cell function, despite the ability of the donor $\mathrm{T}_{\text {reg }}$ cells to secrete IL-10. $\mathrm{T}_{\text {reg }}$ cells transferred into $I l 10^{-/-} \mathrm{Rag}^{1^{--}}$recipient mice expanded in number in vivo and homed to various tissues, including the intestine. However, these cells failed to maintain Foxp3 expression and suppressive activity in the absence of IL-10 signaling.

Despite rigorous sorting of $\mathrm{T}_{\text {reg }}$ cells on the basis of Foxp3 expression, it was possible that a small population $(<1 \%)$ of contaminating activated effector $\mathrm{T}$ cells outgrew the transferred Foxp $^{+} \mathrm{T}_{\text {reg }}$ cells. However, the results from an experiment in which we deliberately transferred congenic activated memory cells together with $\mathrm{T}_{\text {reg }}$ cells demonstrated that these cells did not outgrow the $\mathrm{T}_{\text {reg }}$ cells in $I l 10^{-/}$Rag $^{-/-}$recipients. Therefore, loss of Foxp3 expression is the most plausible explanation for the ineffectiveness of $\mathrm{T}_{\text {reg }}$ cells in the absence of IL-10 signaling.

Studies have indicated that the phenotype and function of $\mathrm{T}_{\text {reg }}$ cells can be unstable. For example, a minority of $\mathrm{T}_{\text {reg }}$ cells lose Foxp3 expression in vitro when IL-6 is added ${ }^{24}$. Also, antibody ligation of $\mathrm{T}$ cell immunoglobulin mucin 1 causes loss of Foxp3 mRNA expression and $\mathrm{T}_{\text {reg }}$ cell function in vitro ${ }^{25}$. The effect of engagement of $\mathrm{T}$ cell immunoglobulin mucin 1 on Foxp $3^{+}$cells by its ligand Tim- 4 in vivo remains to be analyzed. In addition, a subpopulation of CD25-Foxp $3^{+} \mathrm{T}_{\text {reg }}$ cells has a tendency to lose Foxp3 expression ${ }^{26}$. However, we excluded that subset from our analysis, as our $\mathrm{T}_{\text {reg }}$ cell populations were selected for high expression of CD25. Moreover, transferred $\mathrm{T}_{\text {reg }}$ cells can generate follicular helper $\mathrm{T}$ cells in the Peyer's patches under the influence of CD40 expression by B lymphocytes ${ }^{27}$. A study using a Foxp3 reporter lineage marker system has shown that there is some spontaneous loss of Foxp3 expression in vivo, which is enhanced in nonobese diabetic mice with autoimmune disease ${ }^{28}$. As in our experiments, these formerly $\mathrm{T}_{\text {reg }}$ cells secrete proinflammatory cytokines.

Many cell types, including mast cells, epithelial cells and dendritic cells, synthesize IL-10 (refs. 29-32). Our data have indicated that a population of $\mathrm{CD}^{-} 1 \mathrm{~b}^{+}$myeloid cells in the LPL constitutively produced IL-10 and that a phenotypically similar population of IL-10producing cells was greater in abundance in the MLNs early after T cell transfer. Many of the IL-10-producing myeloid cells were probably macrophages, given their expression of F4/80, although we did not exclude the possibility that other cell types were involved. Our findings are in agreement with the results of a study showing that IL-10 from lamina propria macrophages is important for the induction of Foxp3 expression ${ }^{33}$. However, that investigation focused on cells from the small intestine rather than the large intestine and studied induction rather than the maintenance of Foxp3 expression. Despite that, the concept is emerging that intestinal macrophages are important for supporting natural and induced $\mathrm{T}_{\text {reg }}$ cell function.

Why is $\mathrm{T}_{\text {reg }}$ cell-derived IL-10 not sufficient for the maintenance of Foxp3 expression in mice developing colitis? We suggest that the requirement for host cell-derived IL-10 is a matter of kinetics. At early time points, few $\mathrm{T}_{\text {reg }}$ cells were producing IL-10, although at 6 
weeks after transfer, $\mathrm{T}_{\text {reg }}$ cells in the intestine were the main IL-10 producers. Our data therefore suggest that $\mathrm{T}_{\text {reg }}$ cell-derived IL-10 cannot sustain Foxp3 expression because it is induced relatively late.

The outcome of the transfer of $1 l 10 \mathrm{rb}^{-1-} \mathrm{T}_{\text {reg }}$ cells suggested that the IL-10 produced by cells in the $\mathrm{Ragl}^{-1-}$ hosts acted in part directly on the $\mathrm{T}_{\text {reg }}$ cells to maintain Foxp3 expression, although these findings do not exclude the possibility that IL-10 serves additional functions by acting on other cell types that might influence $\mathrm{T}_{\text {reg }}$ cell function. A caveat to our conclusion is that IL-10R $\beta$ can participate in the signals delivered by several other cytokines ${ }^{34}$. However, the concordance with the results obtained from transfer to $I l 10^{-/-} \mathrm{Ragl}^{-/-}$recipients suggests that the ineffectiveness of the $1110 \mathrm{rb}^{-/-} \mathrm{T}_{\text {reg }}$ cells was due to the absence of $\mathrm{T}_{\text {reg }}$ cell IL-10 signaling.

Our data have indicated that colitis in the $\mathrm{Ragl}^{-1-}$ recipients also contributed to the loss of $\mathrm{T}_{\text {reg }}$ cell Foxp3 expression. At relatively early times after transfer, when inflammation was less severe, the loss of Foxp3 was less pronounced and more localized to the intestine. However, Foxp $3^{+} \mathrm{T}$ lymphocytes developed in essentially normal numbers in $1110 \mathrm{rb}^{-1-}$ mice. The $1110 \mathrm{rb}^{-1-}$ mice we used were mainly on the colitis-resistant C57BL/6 background and were only $8-10$ weeks old, and therefore they did not have signs of colitis (data not shown). The results from the transfer of mixed populations of $T_{\text {reg }}$ cells into recipients that developed colitis indicated that colitis alone could not explain the loss of Foxp3.

Furthermore, Foxp3 expression was not much lower in $1110 \mathrm{rb}^{-/-} \mathrm{T}_{\text {reg }}$ cells in recipients of mixed $\mathrm{T}_{\text {reg }}$ cell populations that did not develop colitis. We conclude, therefore, that the combined effects of the absence of IL-10 signaling and the inflammatory milieu in mice with severe colitis were responsible for loss of Foxp3 expression and $\mathrm{T}_{\text {reg }}$ cell function.

\section{METHODS}

Methods and any associated references are available in the online version of the paper at http://www.nature.com/natureimmunology/.

\section{Supplementary Material}

Refer to Web version on PubMed Central for supplementary material.

\section{Acknowledgments}

We thank M. Steinberg and D. Mucida for critical reading of this manuscript, members of the Kronenberg and Cheroutre laboratories for discussions; Y. Wang-Zhu for genotyping mice; L. Fernandez, C. Kim and B. Sears for assistance with cell sorting; P. Allen (Washington University) for $1110 \mathrm{rb}^{-1-}$ mice; and A. Rudensky (Memorial Sloan Kettering Cancer Center) for Foxp 3 gfp mice. Supported by US National Institutes of Health (PO1 DK46763 to M.K., RO1 AI057992 to C.L.K. and RO1 AI50265 to H.C.) and the Crohn's \& Colitis Foundation of America (M.K. and M.M.).

\section{References}

1. Powrie F, Leach MW, Mauze S, Caddle LB, Coffman RL. Phenotypically distinct subsets of CD4 ${ }^{+}$ $\mathrm{T}$ cells induce or protect from chronic intestinal inflammation in C. B-17 scid mice. Int. Immunol 1993;5:1461-1471. [PubMed: 7903159]

2. Powrie $\mathrm{F}$, et al. Inhibition of Th1 responses prevents inflammatory bowel disease in scid mice reconstituted with $\mathrm{CD}_{45 \mathrm{RB}^{\mathrm{hi}}} \mathrm{CD}^{+}{ }^{+} \mathrm{T}$ cells. Immunity 1994;1:553-562. [PubMed: 7600284]

3. Powrie F, Correa-Oliveira R, Mauze S, Coffman RL. Regulatory interactions between CD45RB high and $\mathrm{CD} 45 \mathrm{RB}^{\text {low }} \mathrm{CD} 4^{+} \mathrm{T}$ cells are important for the balance between protective and pathogenic cell-mediated immunity. J. Exp. Med 1994;179:589-600. [PubMed: 7905019] 
4. Mottet C, Uhlig HH, Powrie F. Cutting edge: cure of colitis by $\mathrm{CD} 4{ }^{+} \mathrm{CD} 25^{+}$regulatory T cells. J. Immunol 2003;170:3939-3943. [PubMed: 12682220]

5. Annacker $\mathrm{O}$, et al. $\mathrm{CD} 25^{+} \mathrm{CD} 4^{+} \mathrm{T}$ cells regulate the expansion of peripheral $\mathrm{CD} 4 \mathrm{~T}$ cells through the production of IL-10. J. Immunol 2001;166:3008-3018. [PubMed: 11207250]

6. Gavin MA, et al. Foxp3-dependent programme of regulatory T-cell differentiation. Nature 2007;445:771-775. [PubMed: 17220874]

7. Kuhn R, Lohler J, Rennick D, Rajewsky K, Muller W. Interleukin-10-deficient mice develop chronic enterocolitis. Cell 1993;75:263-274. [PubMed: 8402911]

8. Spencer SD, et al. The orphan receptor CRF2-4 is an essential subunit of the interleukin 10 receptor. J. Exp. Med 1998;187:571-578. [PubMed: 9463407]

9. Roers A, et al. T cell-specific inactivation of the interleukin 10 gene in mice results in enhanced $\mathrm{T}$ cell responses but normal innate responses to lipopolysaccharide or skin irritation. J. Exp. Med 2004;200:1289-1297. [PubMed: 15534372]

10. Rubtsov YP, et al. Regulatory T cell-derived interleukin-10 limits inflammation at environmental interfaces. Immunity 2008;28:546-558. [PubMed: 18387831]

11. Hagenbaugh A, et al. Altered immune responses in interleukin 10 transgenic mice. J. Exp. Med 1997;185:2101-2110. [PubMed: 9182682]

12. Groux $\mathrm{H}$, et al. A CD4 ${ }^{+} \mathrm{T}$-cell subset inhibits antigen-specific T-cell responses and prevents colitis. Nature 1997;389:737-742. [PubMed: 9338786]

13. Asseman C, Mauze S, Leach MW, Coffman RL, Powrie F. An essential role for interleukin 10 in the function of regulatory T cells that inhibit intestinal inflammation. J. Exp. Med 1999;190:9951004. [PubMed: 10510089]

14. Asseman C, Read S, Powrie F. Colitogenic Th1 cells are present in the antigen-experienced T cell pool in normal mice: control by $\mathrm{CD}^{+}{ }^{+}$regulatory T cells and IL-10. J. Immunol 2003;171:971978. [PubMed: 12847269]

15. Uhlig HH, et al. Characterization of Foxp $3^{+} \mathrm{CD} 4{ }^{+} \mathrm{CD} 25^{+}$and IL-10-secreting CD $4^{+} \mathrm{CD} 25^{+} \mathrm{T}$ cells during cure of colitis. J. Immunol 2006;177:5852-5860. [PubMed: 17056509]

16. Fontenot JD, et al. Regulatory $\mathrm{T}$ cell lineage specification by the forkhead transcription factor foxp3. Immunity 2005;22:329-341. [PubMed: 15780990]

17. Marie JC, Letterio JJ, Gavin M, Rudensky AY. TGF- $\beta 1$ maintains suppressor function and Foxp3 expression in CD4 ${ }^{+}$CD25v regulatory T cells. J. Exp. Med 2005;201:1061-1067. [PubMed: 15809351]

18. Fahlen $\mathrm{L}$, et al. $\mathrm{T}$ cells that cannot respond to TGF- $\beta$ escape control by $\mathrm{CD} 4{ }^{+} \mathrm{CD} 25^{+}$regulatory $\mathrm{T}$ cells. J. Exp. Med 2005;201:737-746. [PubMed: 15753207]

19. Li MO, Sanjabi S, Flavell RA. Transforming growth factor- $\beta$ controls development, homeostasis, and tolerance of $\mathrm{T}$ cells by regulatory $\mathrm{T}$ cell-dependent and -independent mechanisms. Immunity 2006;25:455-471. [PubMed: 16973386]

20. Marie JC, Liggitt D, Rudensky AY. Cellular mechanisms of fatal early-onset autoimmunity in mice with the T cell-specific targeting of transforming growth factor-beta receptor. Immunity 2006;25:441-454. [PubMed: 16973387]

21. Li MO, Wan YY, Flavell RA. T cell-produced transforming growth factor- $\beta 1$ controls T cell tolerance and regulates Th1- and Th17-cell differentiation. Immunity 2007;26:579-591. [PubMed: 17481928]

22. Liu Y, et al. A critical function for TGF- $\beta$ signaling in the development of natural $\mathrm{CD}^{+}{ }^{+} \mathrm{CD} 25^{+} \mathrm{Foxp}^{+}$regulatory T cells. Nat. Immunol 2008;9:632-640. [PubMed: 18438410]

23. Roncarolo MG, et al. Interleukin-10-secreting type 1 regulatory $\mathrm{T}$ cells in rodents and humans. Immunol. Rev 2006;212:28-50. [PubMed: 16903904]

24. Xu L, Kitani A, Fuss I, Strober W. Cutting edge: regulatory T cells induce CD $4^{+} \mathrm{CD} 25^{-}$Foxp $3{ }^{-} \mathrm{T}$ cells or are self-induced to become Th17 cells in the absence of exogenous TGF- $\beta$. J. Immunol 2007;178:6725-6729. [PubMed: 17513718]

25. Degauque N, et al. Immunostimulatory Tim-1-specific antibody deprograms Tregs and prevents transplant tolerance in mice. J. Clin. Invest 2008;118:735-741. [PubMed: 18079964] 
26. Komatsu N, et al. Heterogeneity of natural Foxp $3^{+} \mathrm{T}$ cells: a committed regulatory T-cell lineage and an uncommitted minor population retaining plasticity. Proc. Natl. Acad. Sci. USA 2009;106:1903-1908. [PubMed: 19174509]

27. Tsuji M, et al. Preferential generation of follicular B helper T cells from Foxp3 ${ }^{+} \mathrm{T}$ cells in gut Peyer's patches. Science 2009;323:1488-1492. [PubMed: 19286559]

28. Zhou X, et al. Instability of the transcription factor Foxp3 leads to the generation of pathogenic memory T cells in vivo. Nat. Immunol 2009;10:1000-1007. [PubMed: 19633673]

29. Mizoguchi A, Mizoguchi E, Takedatsu H, Blumberg RS, Bhan AK. Chronic intestinal inflammatory condition generates IL-10-producing regulatory B cell subset characterized by CD1d upregulation. Immunity 2002;16:219-230. [PubMed: 11869683]

30. Grimbaldeston MA, Nakae S, Kalesnikoff J, Tsai M, Galli SJ. Mast cell-derived interleukin 10 limits skin pathology in contact dermatitis and chronic irradiation with ultraviolet B. Nat. Immunol 2007;8:1095-1104. [PubMed: 17767162]

31. De Winter H, et al. Regulation of mucosal immune responses by recombinant interleukin 10 produced by intestinal epithelial cells in mice. Gastroenterology 2002;122:1829-1841. [PubMed: 12055591]

32. Brooks DG, et al. Interleukin-10 determines viral clearance or persistence in vivo. Nat. Med 2006;12:1301-1309. [PubMed: 17041596]

33. Denning TL, Wang YC, Patel SR, Williams IR, Pulendran B. Lamina propria macrophages and dendritic cells differentially induce regulatory and interleukin 17-producing T cell responses. Nat. Immunol 2007;8:1086-1094. [PubMed: 17873879]

34. Donnelly RP, Sheikh F, Kotenko SV, Dickensheets H. The expanded family of class II cytokines that share the IL-10 receptor-2 (IL-10R2) chain. J. Leukoc. Biol 2004;76:314-321. [PubMed: 15123776] 


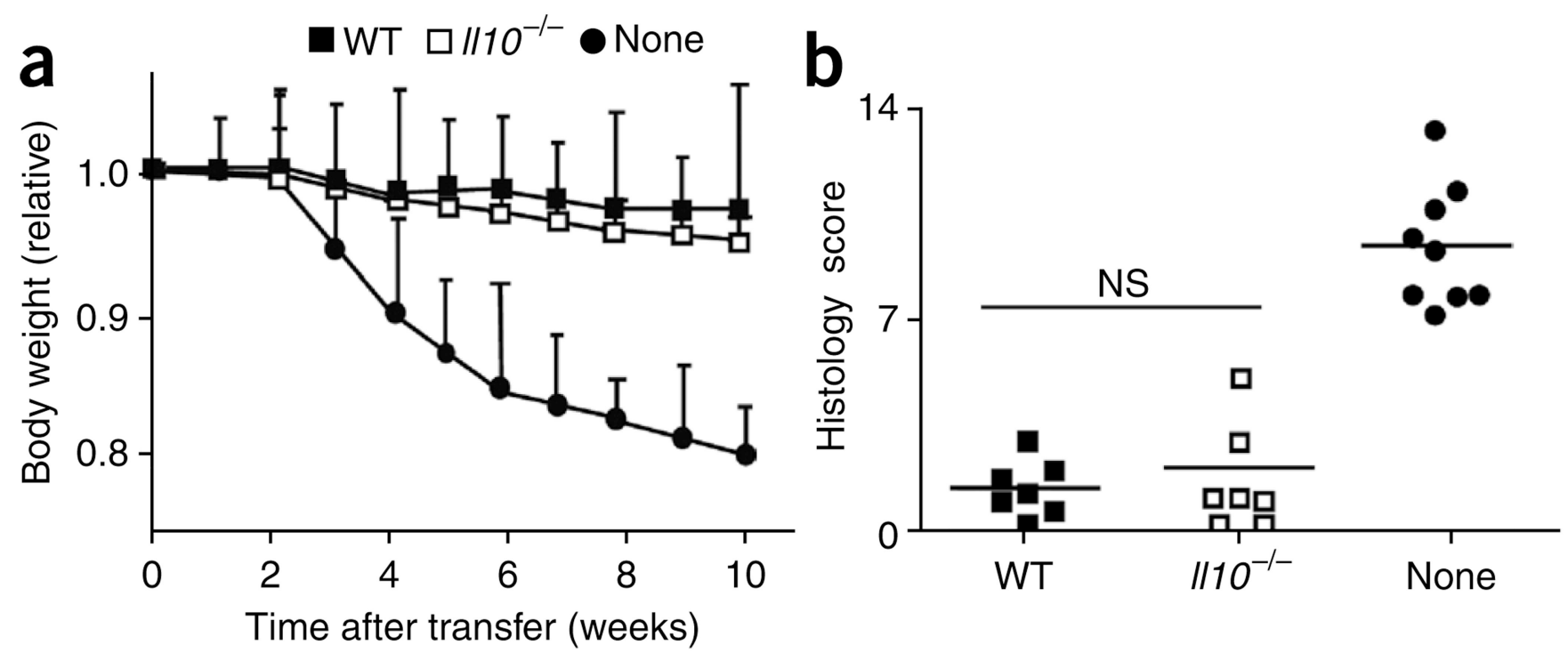

Figure 1.

IL-10-deficient $\mathrm{T}_{\text {reg }}$ cells prevent colitis. (a) Body weight of $\mathrm{Ragl}^{-/-}$mice given sorted $I l 10^{-/-}$or wild-type (WT) $\mathrm{CD} 4^{+} \mathrm{CD} 25^{+} \mathrm{T}_{\text {reg }}$ cells, together with $\mathrm{CD} 4{ }^{+} \mathrm{CD} 45 \mathrm{RB}{ }^{\text {hi }} \mathrm{T}$ cells, or of $\mathrm{Ragl}^{-/-}$mice given $\mathrm{CD} 4{ }^{+} \mathrm{CD} 45 \mathrm{RB}^{\text {hi }} \mathrm{T}$ cells alone (control; None), presented relative to initial body weight. Data are pooled from two independent experiments with six mice each (error bars, s.d.). (b) Histology scores of sections of the large intestine at 6 weeks after the cell transfer described in a. Each symbol represents an individual mouse; small horizontal lines indicate the mean. NS, not significant. Data are pooled from at least two independent experiments. 

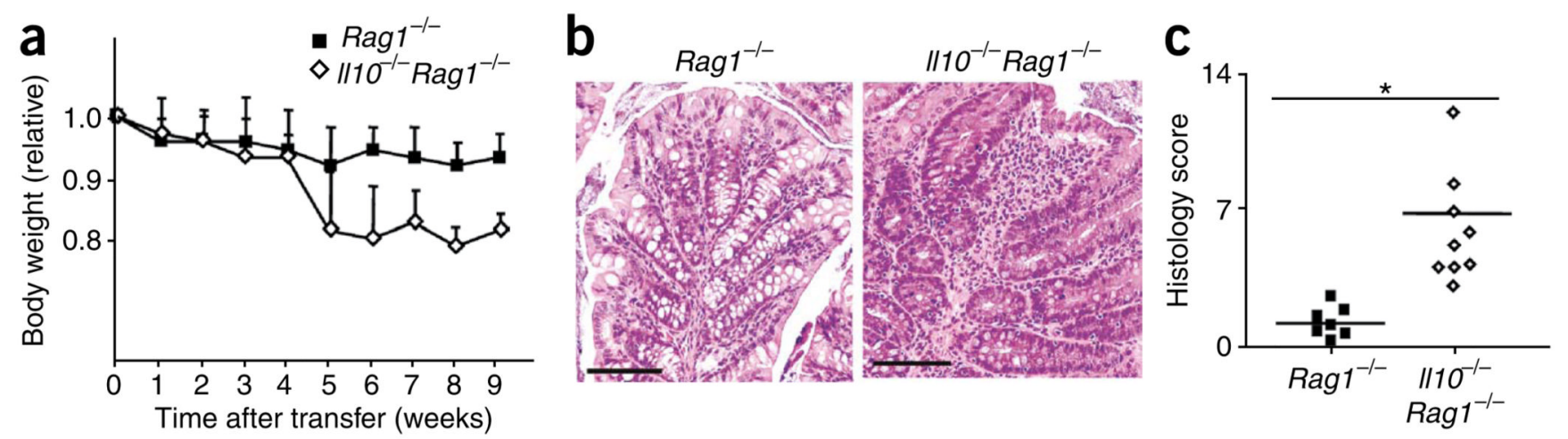

Figure 2.

Ragl ${ }^{-/-}$host IL-10 is required for $\mathrm{T}_{\text {reg }}$ cell function. (a) Body weight of $R a g 1^{-/-}$or IllO ${ }^{-I-}$ Rag $1^{-l-}$ hosts given CD $4^{+} \mathrm{CD} 45 \mathrm{RB}{ }^{\text {hi }} \mathrm{T}$ cells plus sorted Foxp $3^{\mathrm{gfp}} \mathrm{T}_{\text {reg }}$ cells, presented relative to initial body weight. Data are pooled from two independent experiments with ten mice each (error bars, s.d.). (b) Proximal colon of $\mathrm{Ragl}^{-/-}$and $I l 1 \mathrm{O}^{-/-} \mathrm{Ragl}^{-/-}$ mice at 6 weeks after the donor cell transfer described in $\mathbf{a}$; sections are stained with hematoxylin and eosin. Original magnification, $\times 100$; scale bars, $100 \mu \mathrm{m}$. Data are representative of one of three independent experiments. (c) Histology scores of sections of the large intestine at 6 weeks after the cell transfer described in $\mathbf{a}$. Each symbol represents an individual mouse; small horizontal lines indicate the mean. $* P<0.001$ (two-tailed Student's $t$-test). Data are pooled from three independent experiments with a total of nine mice. 

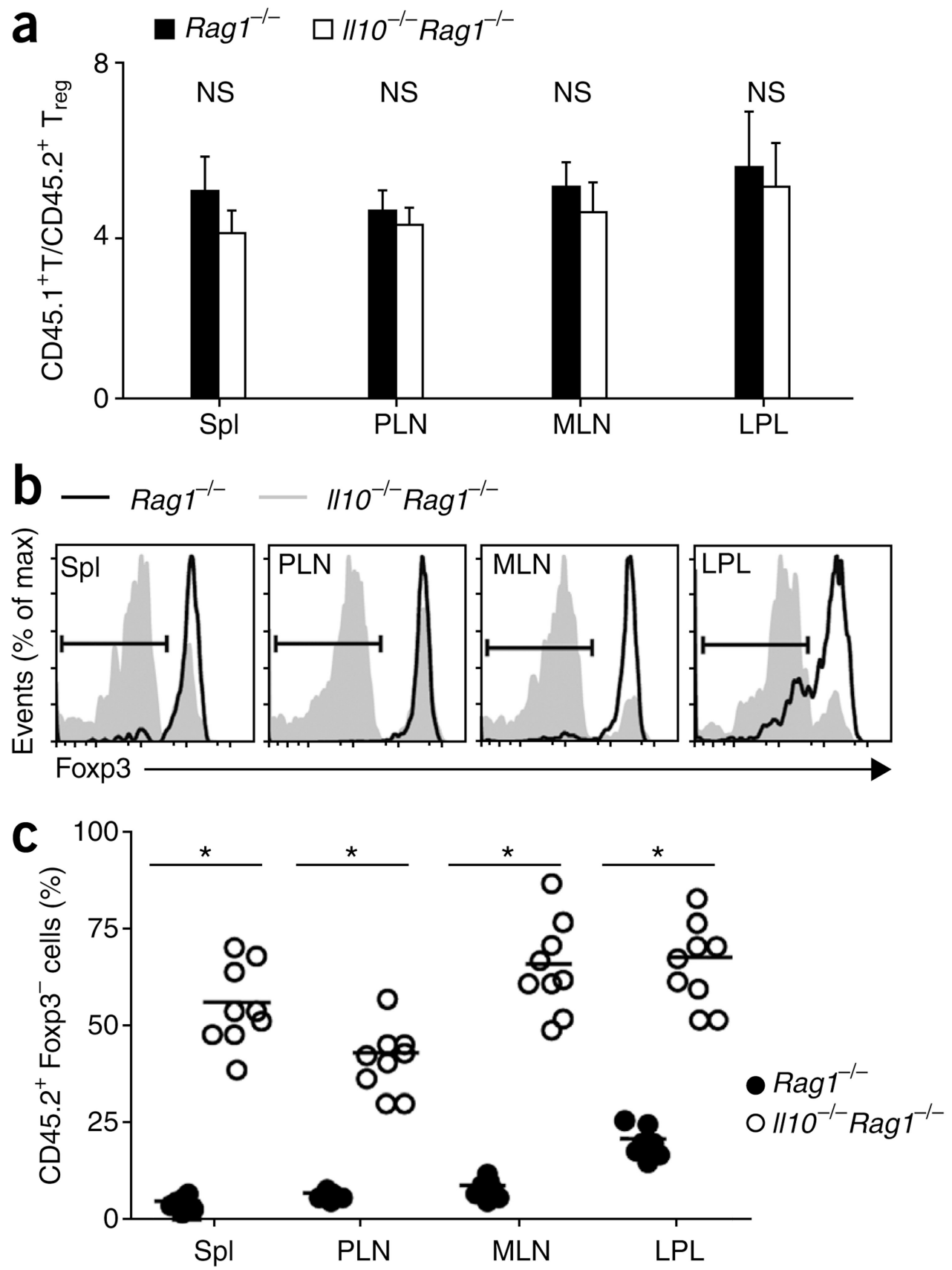

Figure 3.

Foxp3 is downregulated in $I l 10^{-/-} \mathrm{Ragl}^{-/-}$recipients. (a) Composite ratios of CD45.1 $1^{+}$to CD45.2 $2^{+} \mathrm{TCR} \beta^{+} \mathrm{CD} 4^{+}$cells in the spleen (Spl), PLNs, MLNs and LPL of $\mathrm{Ragl}^{-1-}$ or $I l 10^{-/} \mathrm{Rag}^{-/-}$recipient mice at 6 weeks after injection of $4 \times 10^{5} \mathrm{CD} 4{ }^{+} \mathrm{CD} 45 \mathrm{RB}^{\text {hi }} \mathrm{T}$ cells derived from C57BL/6 $\left(\right.$ CD45.1 $\left.{ }^{+}\right)$mice, plus $1 \times 10^{5}$ Foxp $3^{\text {gfp }}\left(\mathrm{CD} 45.2^{+}\right) \mathrm{T}_{\text {reg }}$ cells. (b) Foxp3 expression in the cells in a, gated on TCR $\beta^{+} \mathrm{CD} 4^{+} \mathrm{CD} 45.2^{+}$cells. Bracketed lines indicate the Foxp $3^{-}$population. max, maximum. (c) Foxp3 $3^{-}$cells in the gated TCR $\beta^{+} \mathrm{CD} 4^{+}$ CD $45.2^{+}$populations in $\mathbf{b}$. Each symbol represents an individual mouse; small horizontal lines indicate the mean. ${ }^{*} P<0.001$ (two-tailed Student's $t$-test). Data are pooled from three 
independent experiments with a total of nine mice (a (mean and s.d.) and $\mathbf{c}$ ) or are representative of one of three independent experiments (b). 


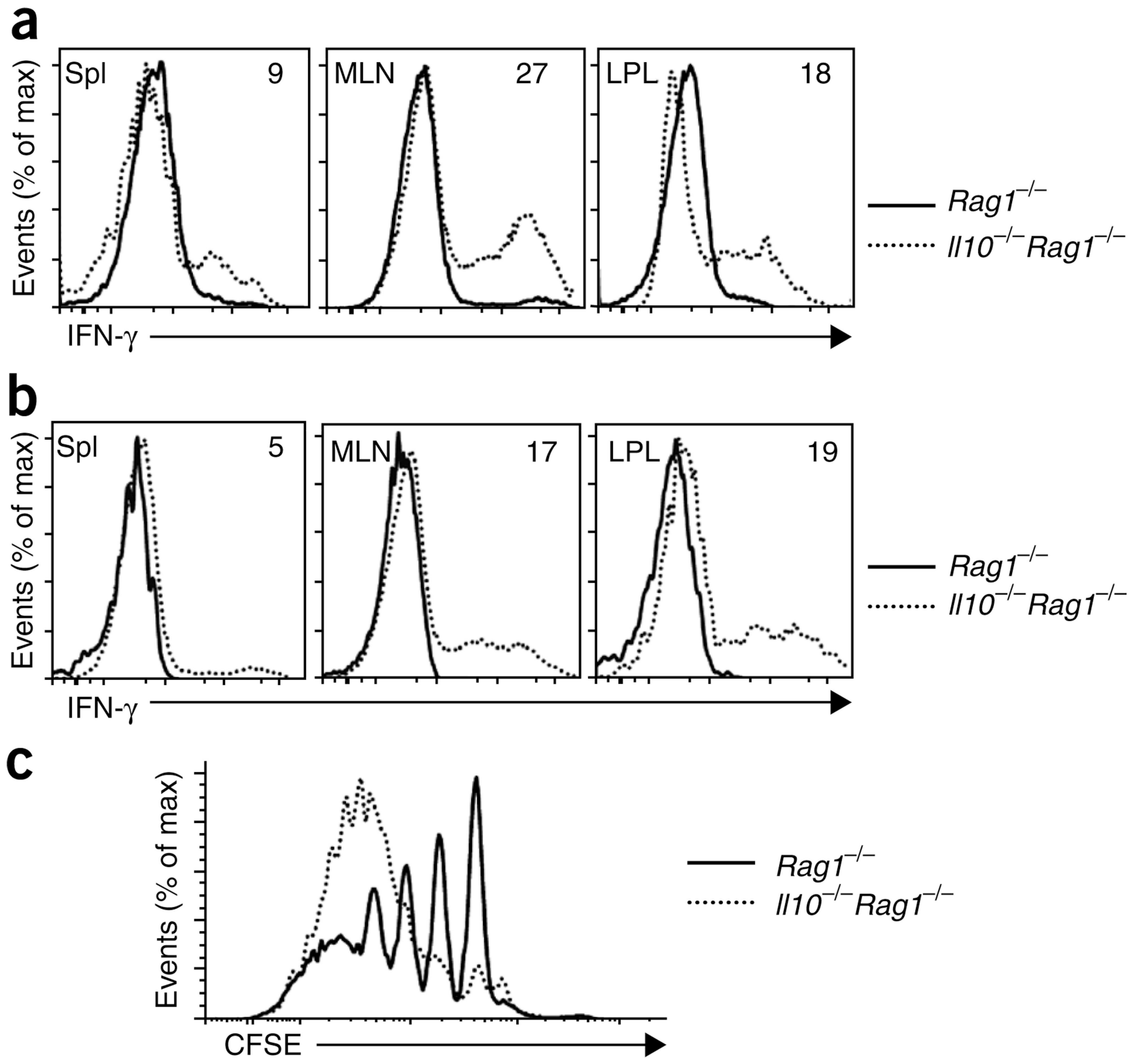

Figure 4.

Loss of function by $\mathrm{T}_{\text {reg }}$ cells from $I l 10^{-/-} \mathrm{Ragl}^{-/-}$recipients. (a,b) Flow cytometry of intracellular IFN- $\gamma$ in CD4 ${ }^{+} \mathrm{CD} 45 \mathrm{RB}^{\text {hi }} \mathrm{T}$ cells derived from C57BL/6 (CD45.1 ${ }^{+}$) mice transferred with Foxp $3^{\text {gfp }}\left(\mathrm{CD} 45.2^{+}\right) \mathrm{T}_{\text {reg }}$ cells into Rag $1^{-/-}$or $I l 10^{-/-}$Rag $^{-1-}$ hosts; plots are gated on the $\mathrm{TCR} \beta^{+} \mathrm{CD} 4^{+} \mathrm{CD} 45.2^{-}$progeny of donor $\mathrm{CD} 4^{+} \mathrm{CD} 45 \mathrm{RB}^{\text {hi }} \mathrm{T}$ cells $(\mathbf{a})$ and the $\mathrm{TCR} \beta^{+} \mathrm{CD} 4^{+} \mathrm{CD} 45.2^{+}$progeny from donor Foxp $3^{\mathrm{gfp}}+\mathrm{T}_{\text {reg }}$ cells $(\mathbf{b})$, isolated from spleen (Spl), MLNs and LPL in mice at 6 weeks after donor cell injection and then stimulated with PMA and ionomycin. Numbers in plots indicate percent IFN- $\gamma$-producing cells. (c) Suppressive function in vitro of sorted TCR $\beta^{+} \mathrm{CD} 4^{+} \mathrm{CD} 45.2^{+}$cells from MLNs of Rag $1^{-/-}$or $I l 10^{-/-} \mathrm{Ragl}^{-/-}$recipients of CD 45. $1^{+} \mathrm{CD}^{+}{ }^{+} \mathrm{CD} 45 \mathrm{RB}^{\text {hi }}$ and CD45.2 ${ }^{+}$

$\mathrm{CD} 4^{+} \mathrm{CD} 25^{+} \mathrm{CD} 45 \mathrm{RB}^{\text {lo }} \mathrm{T}_{\text {reg }}$ cell populations, cultured for $4 \mathrm{~d}$ together with CFSE-labeled 
CD45. $1^{+}$naive T cells; after stimulation of cultures, CFSE dilution was assessed by flow cytometry. Data are representative of one of three $(\mathbf{a}, \mathbf{b})$ or two $(\mathbf{c})$ independent experiments. 


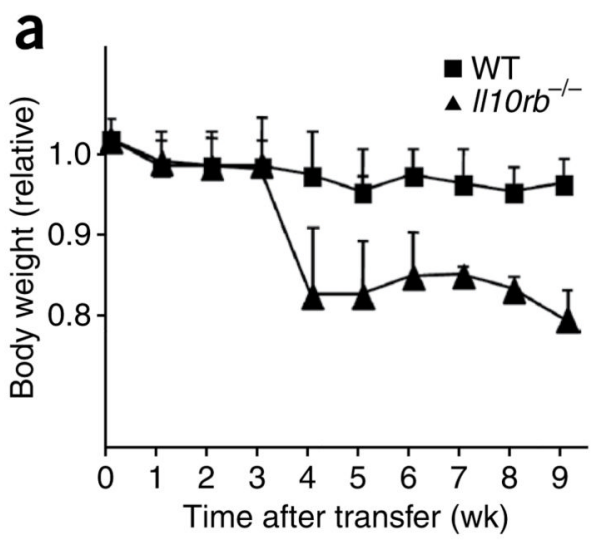

d

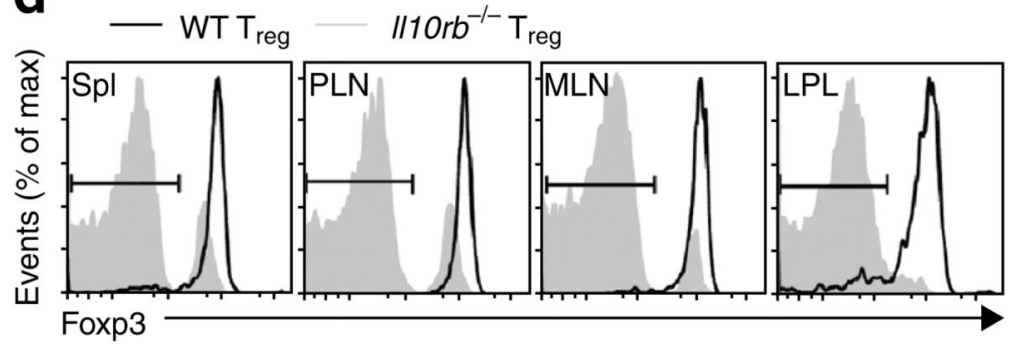

b
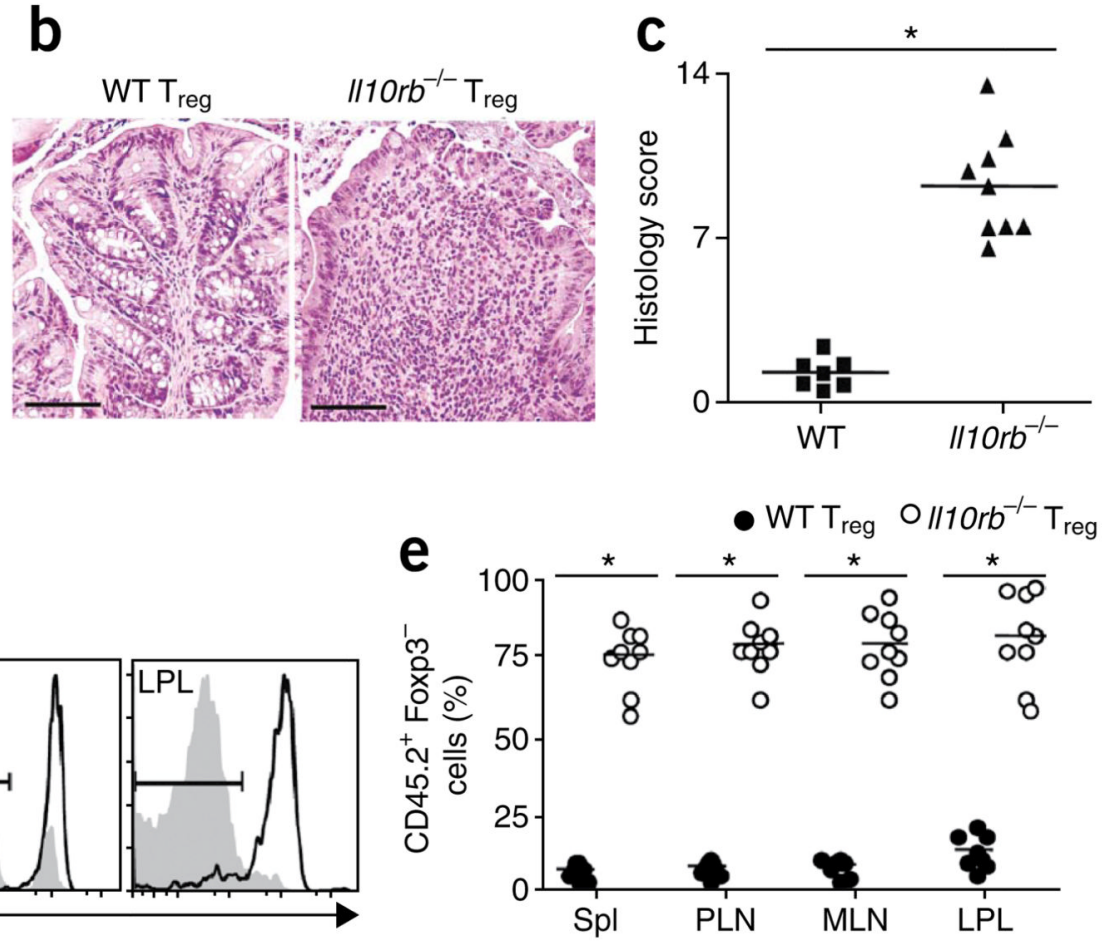

Figure 5.

IllOrb ${ }^{-1-} \mathrm{T}_{\text {reg }}$ cells fail to prevent colitis. (a) Body weight of $\mathrm{Ragl}^{-/-}$recipients of C57BL/6

$\left(\mathrm{CD} 45.1^{+}\right) \mathrm{CD} 4{ }^{+} \mathrm{CD} 45 \mathrm{RB}^{\text {hi }} \mathrm{T}$ cells transferred together with wild-type or $1110 \mathrm{rb}^{-/-}$

$\left(\mathrm{CD} 45.2^{+}\right) \mathrm{T}_{\text {reg }}$ cells, presented relative to initial body weight. Data are pooled from two independent experiments with a total of ten mice (error bars, s.d.). (b) Proximal colon of recipient mice at 6 weeks after injection of cells as described in $\mathbf{a}$; sections are stained with hematoxylin and eosin. Original magnification, $\times 100$; scale bars, $100 \mu \mathrm{m}$. Data are representative of one of three independent experiments. (c) Histology scores of sections of the large intestine at 6 weeks after the cell transfer described in a. Each symbol represents an individual mouse; small horizontal lines indicate the mean. $* P<0.001$ (two-tailed Student's $t$-test). Data are pooled from three independent experiments with a total of nine mice. (d) Foxp3 expression by cells isolated from the spleen, PLNs, MLNs and LPL of the recipient mice in a, with gating on TCR $\beta^{+} \mathrm{CD} 4^{+} \mathrm{CD} 45.2^{+}$cells. Bracketed lines indicate the Foxp $3^{-}$ population. Data are representative of one of three independent experiments with a total of nine mice. (e) Foxp3 ${ }^{-}$cells in the TCR $\beta^{+} \mathrm{CD} 4^{+} \mathrm{CD} 45.2^{+} \mathrm{T}$ lymphocyte populations described in d. Each symbol represents an individual mouse; small horizontal bars indicate the mean. ${ }^{*} P<0.001$ (two-tailed Student's $t$-test). Data are pooled from three independent experiments with a total of nine mice. 


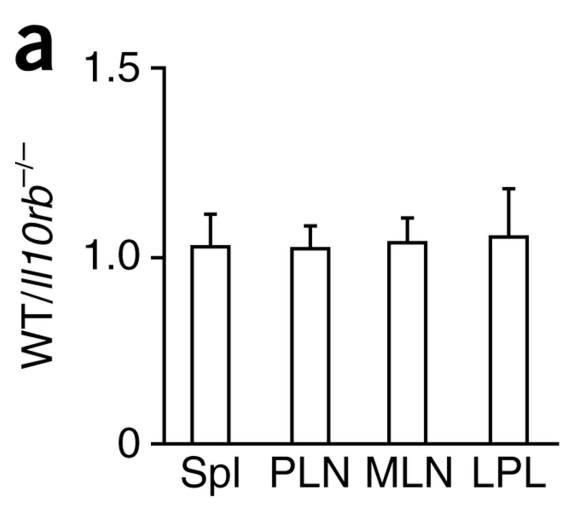

b - WT Treg

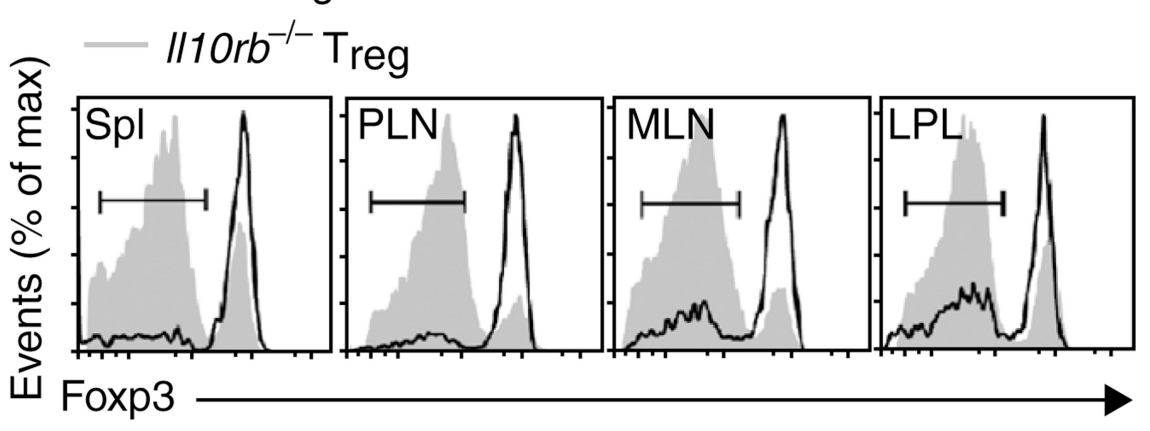

C

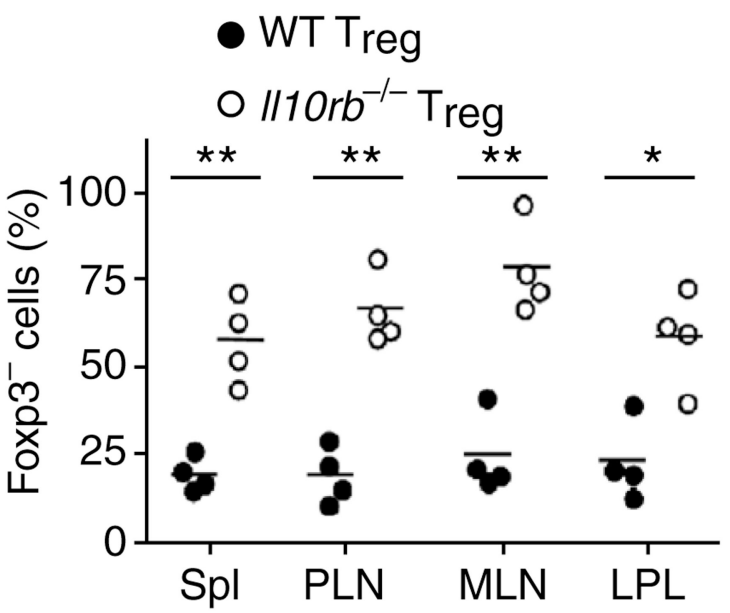

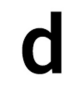

d
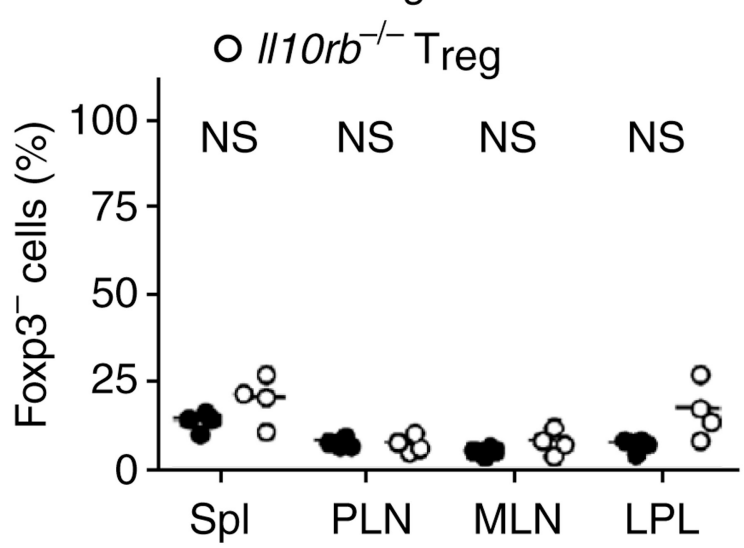

Figure 6.

Foxp3 is lost 'preferentially' by $I l 10 \mathrm{rb}^{-1-} \mathrm{T}_{\text {reg }}$ cells in mice with colitis. (a) Ratio of $\mathrm{CD} 45.1^{+}$to CD45.2 ${ }^{+} \mathrm{CD} 90.1^{-} \mathrm{CD}^{+} \mathrm{TCR} \beta^{+}$cells isolated from spleen, PLNs, MLNs and LPL of $\mathrm{Ragl}^{-/-}$recipients at 6 weeks after injection of $8 \times 10^{5} \mathrm{C} 57 \mathrm{BL} / 6\left(\mathrm{CD} 90.1^{+}\right)$ $\mathrm{CD}^{+}{ }^{+} \mathrm{CD} 45 \mathrm{RB}^{\text {hi }} \mathrm{T}$ cells, transferred with $2 \times 10^{4}$ wild-type $\left(\mathrm{CD} 45.1^{+}\right) \mathrm{T}_{\text {reg }}$ cells and $2 \times 10^{4}$ Illorb ${ }^{-1-}\left(\mathrm{CD} 45.2^{+}\right) \mathrm{T}_{\text {reg }}$ cells. Data are pooled from two independent experiments with a total of four mice (mean and s.d.). (b) Flow cytometry of Foxp3 expression by cells isolated from a $\mathrm{Ragl}^{-/-}$recipient mouse as described in a, with gating on CD90.1 $1^{-} \mathrm{CD}^{+}{ }^{\mathrm{TCR}} \beta^{+} \mathrm{CD} 45.2^{-}$cells (wild-type $\mathrm{T}_{\text {reg }}$ cells) or CD90.1 ${ }^{-} \mathrm{CD} 4^{+} \mathrm{TCR} \beta^{+} \mathrm{CD} 45.2^{+}$ cells $\left(\right.$ IllOrb ${ }^{-1-} \mathrm{T}_{\text {reg }}$ cells). Bracketed lines indicate the Foxp3 ${ }^{-}$population. Data are representative of one of two independent experiments. (c) Foxp3 $3^{-}$cells in the CD90.1 $1^{-} \mathrm{CD}^{+}{ }^{+} \mathrm{TCR} \beta^{+} \mathrm{CD} 45.2^{-}$(wild-type $\mathrm{T}_{\text {reg }}$ ) and CD90.1 ${ }^{-} \mathrm{CD} 4^{+} \mathrm{TCR} \beta^{+} \mathrm{CD} 45.2^{+}$ $\left(\right.$ IllOrb ${ }^{-1-} \mathrm{T}_{\text {reg }}$ ) populations isolated from $\mathrm{Ragl}^{-1-}$ mice as described in a. Each symbol represents an individual mouse; small horizontal bars indicate the mean. Data are pooled from two independent experiments with a total of four mice. (d) Foxp3 ${ }^{-}$cells in CD90.1 ${ }^{-} \mathrm{CD}^{+}{ }^{+} \mathrm{TCR} \beta^{+} \mathrm{CD} 45.2^{-}$(wild-type $\mathrm{T}_{\mathrm{reg}}$ ) or CD90.1 ${ }^{-} \mathrm{CD} 4^{+} \mathrm{TCR} \beta^{+} \mathrm{CD} 45.2^{+}$ $\left(\right.$ IllOrb ${ }^{-/-} \mathrm{T}_{\mathrm{reg}}$ ) populations isolated from $\mathrm{Ragl}^{-/-}$recipients of $4 \times 10^{5} \mathrm{C} 57 \mathrm{BL} / 6$ $\left(\mathrm{CD} 90.1^{+}\right) \mathrm{CD}^{+} \mathrm{CD} 45 \mathrm{RB}^{\text {hi }} \mathrm{T}$ cells, transferred together with $1 \times 10^{5}$ wild-type $\left(\mathrm{CD} 45.1^{+}\right)$ and $1 \times 10^{5} \mathrm{IllOrb}^{-1-}\left(\mathrm{CD} 45.2^{+}\right) \mathrm{T}_{\text {reg }}$ cells. Each symbol represents an individual mouse; small horizontal bars indicate the mean. $* P<0.01$; ** $P<0.001$ (two-tailed Student's $t$ test). Data are pooled from two independent experiments with a total of four mice. 
a

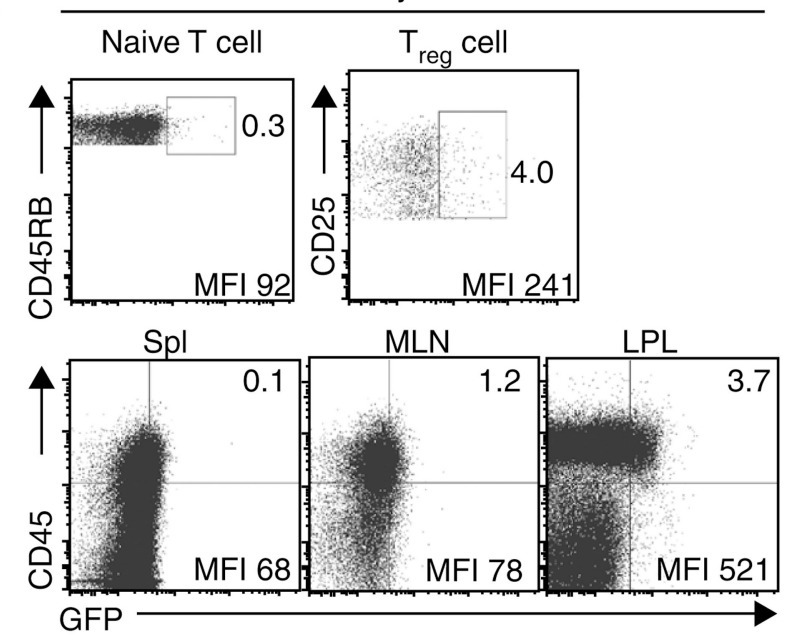

b

Day 7
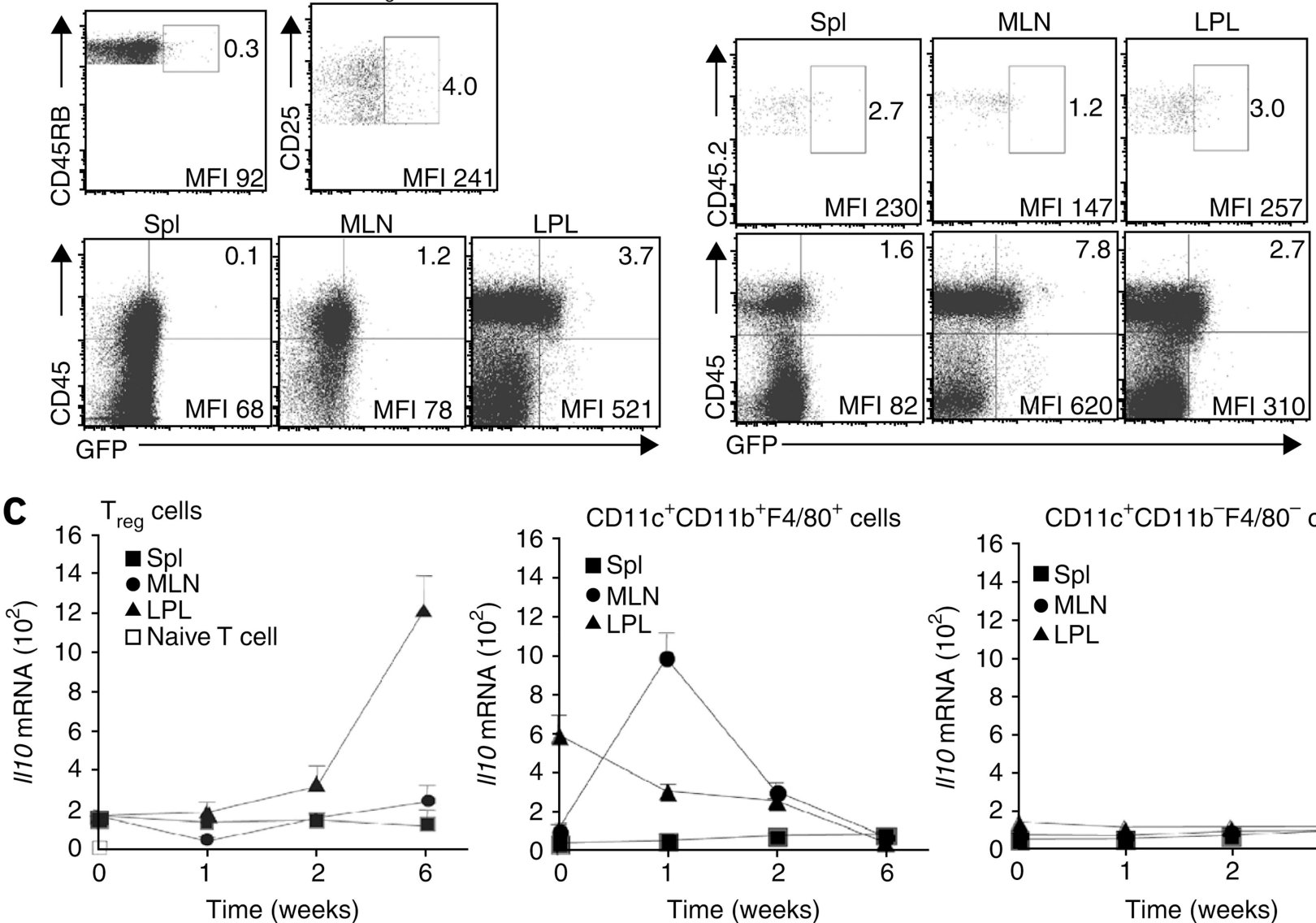

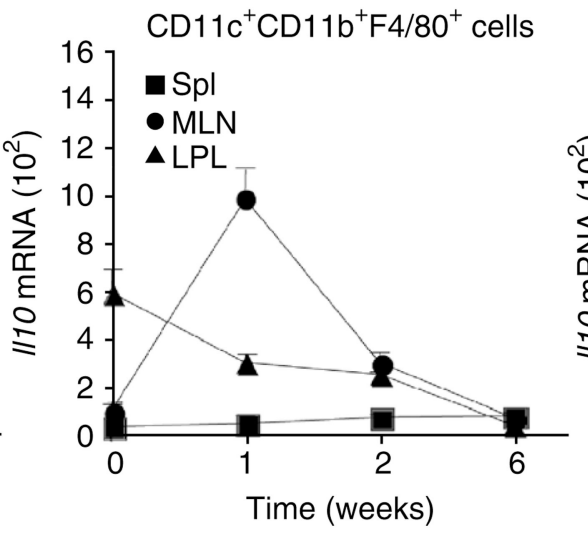

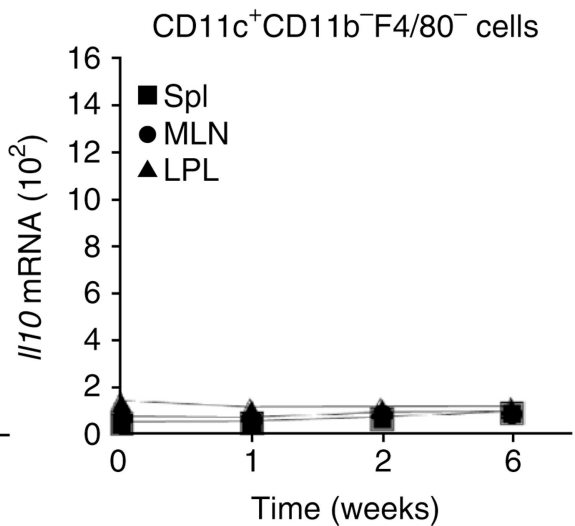

Figure 7.

Kinetics of IL-10 expression by $\mathrm{T}_{\text {reg }}$ cells and host cells. (a) $\mathrm{GFP}^{+}$cells in IL-10 reporter mice. Numbers adjacent to outlined areas (top row) indicate percent $\mathrm{GFP}^{+}$cells among gated naive splenocytes $\left(\mathrm{TCR} \beta^{+} \mathrm{CD} 4^{+} \mathrm{CD} 45 \mathrm{RB}{ }^{\text {hi }}\right)$ and $\mathrm{T}_{\text {reg }}$ splenocytes

$\left(\mathrm{TCR} \beta^{+} \mathrm{CD} 4^{+} \mathrm{CD} 45 \mathrm{RB}^{\mathrm{lo}} \mathrm{CD} 25^{+}\right.$) from $1110^{\text {gfp }}$ mice; numbers in top right quadrants (bottom row) indicate percent $\mathrm{CD} 45^{+} \mathrm{GFP}^{+}$cells in tissues from $1110^{\mathrm{gfp}} \mathrm{Rag} 1^{-1-}$ mice. MFI, mean fluorescence intensity. (b) Flow cytometry of $\mathrm{GFP}^{+}$cells in tissues $7 \mathrm{~d}$ after transfer of a mixture of CD45.1 ${ }^{+} \mathrm{CD}^{+} \mathrm{CD} 45 \mathrm{RB}^{\text {hi }} \mathrm{T}$ cells and CD45.2 ${ }^{+}$Il10 ${ }^{\text {gfp }} \mathrm{T}_{\text {reg }}$ cells (ratio, 4:1). Top row, $\mathrm{T}_{\text {reg }}$ cells gated as $\mathrm{CD} 45.2^{+} \mathrm{TCR}^{+} \mathrm{CD} 4^{+}$cells; bottom row, gated $\mathrm{TCR} \beta^{-} \mathrm{CD} 4^{-}$ nonlymphoid cells. Numbers adjacent to outlined areas and in top right quadrants indicate percent $\mathrm{GFP}^{+}$cells. (c) Real-time PCR analysis of $1110 \mathrm{mRNA}$ in sorted $\mathrm{T}_{\text {reg }}$ cells (left), $\mathrm{CD}_{11} \mathrm{~b}^{+}$cells (middle) and CD11 ${ }^{+}$dendritic cells (right) from various sites (keys) before transfer (0) or at 1, 2 and 6 weeks after transfer as in b. Data are from representative one of two independent experiments with six mice $(\mathbf{a}, \mathbf{b})$ or are pooled from two independent experiments with six mice (c; mean and s.d.). 
a $\quad$ b

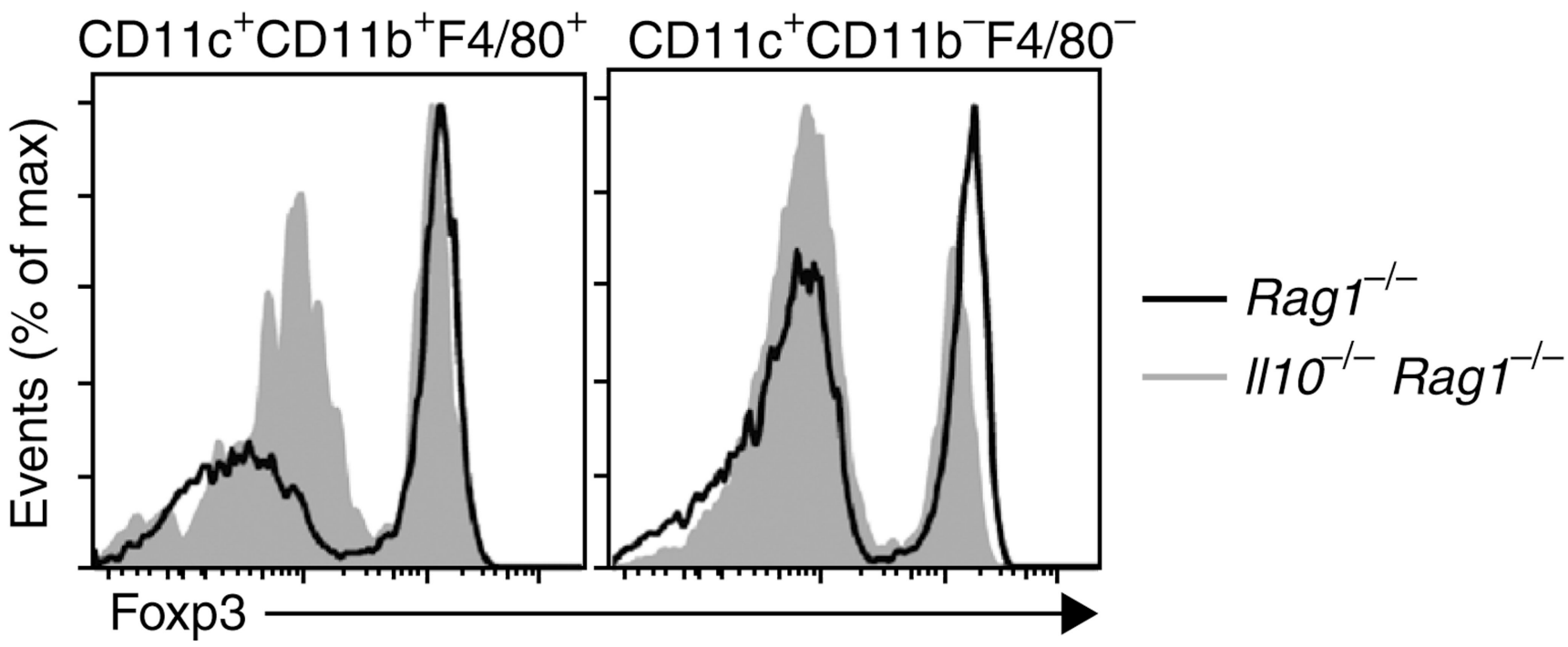

Figure 8.

IL-10-producing CD11 $\mathrm{b}^{+}$myeloid cells prevent the downregulation of Foxp3. Flow cytometry of Foxp3 expression 3 weeks after the injection of $5 \times 10^{6} \mathrm{Ragl}^{-1-}$ or Ill1 ${ }^{-/}$Rag $^{-1-}$ intestinal CD $11 \mathrm{c}^{+} \mathrm{CD} 11 \mathrm{~b}^{+} \mathrm{F} 4 / 80^{+}$cells $(\mathbf{a})$ or $\mathrm{CD} 11 \mathrm{c}^{+} \mathrm{CD} 11 \mathrm{bF} 4 / 80^{-}$cells $(\mathbf{b})$ into $1 l 10^{-I} \mathrm{Ragl}^{-/-}$recipients, transferred intravenously on days 0 and 7 (where 'day 0 ' is the day of T cell transfer) with $4 \times 10^{5} \mathrm{CD}^{+} \mathrm{CD} 45 \mathrm{RB}^{\mathrm{hi}}\left(\mathrm{CD} 45.1^{+}\right)$cells in the presence of $1 \times 10^{5}\left(\mathrm{CD} 45.2^{+}\right) \mathrm{T}_{\text {reg }}$ cells from Foxp $3^{\text {gfp }}$ mice. Plots are gated on TCR $\beta^{+} \mathrm{CD} 4^{+} \mathrm{CD} 45.2^{+}$ splenocytes. Data are representative of one of two independent experiments with a total of three mice. 